\title{
RURAL TEACHERS AND SOCIAL MOVEMENTS UNDER FORMATION: POLITICAL STRUGGLES FOR RURAL SCHOOLS IN NORTHWESTERN RIO DE JANEIRO STATE
}

\section{EDUCADORES DO CAMPO E MOVIMENTOS SOCIAIS EM FORMAÇÃO: EMBATES POLÍTICOS EM DEFESA DAS ESCOLAS DO CAMPO NO NOROESTE FLUMINENSE}

\author{
Francisca Marli Rodrigues de Andrade* \\ Lucas do Couto Neves ${ }^{* *}$
}

\begin{abstract}
Closing rural schools is a scene that has become usual in many Brazilian states, a fact that forces rural communities to quit life in the country as the place for both living and existence reproduction. Rural schools in Northwestern Rio de Janeiro State take the same path of other Brazilian realities; in other words, they are the victims of activity canceling, which is an injustice supported by economic arguments. However, the implementation of the course named Interdisciplinary Major Degree in Rural Education, also known as LEdoC, at Fluminense Federal University (UFF), in Santo Antônio de Pádua City, RJ, opened room for a whole series of popular movements to cope with the rural exodus reality. Accordingly, the aim of the present study is to describe the path opened between 2015 and 2019 by UFF's LEdoC and Santo Antônio de Pádua's community for the Alternation Pedagogy in order to defend rural schools, based on the research-action methodology. The main results have highlighted the importance of the research-action methodology to reinforce the local demands and the process of reporting the alienation of rural populations from their right to education. Moreover, they have pointed towards the fact that popular social movements reinforce rural teachers' formation by repairing public policies to question oppression situations in and outside education institutions.
\end{abstract}

Keywords: Rural Education; Schools' closing; Countryside teachers' training; Social movements.

RESUMO: Fechar escolas do campo é um cenário que tem se consolidado em muitos Estados do Brasil, impondo às comunidades campesinas o apagamento do campo como lugar de reprodução da vida e de existência. No Noroeste Fluminense, as escolas do campo seguem a mesma trajetória de outras realidades brasileiras; ou seja, vítimas das práticas de fechamento, enquanto injustiças arquitetadas em argumentos economicistas. Porém, com a implementação da Licenciatura Interdisciplinar em

\footnotetext{
* Fluminense Federal University (UFF). Contact: marli_andrade@id.uff.br

** University of Brasilia (UnB). Contact: lucasdocouto@yahoo.com.br
} 
Educação do Campo (LEdoC) da Universidade Federal Fluminense (UFF) na cidade de Santo Antônio de Pádua - Rio de Janeiro - uma série de movimentos populares confrontam a realidade de esvaziamento do campo. Nesse sentido, este artigo, com enfoque metodológico da pesquisa-ação, tem como objetivo descrever o caminho que estudantes da LEdoC da UFF e a comunidade de Santo Antônio de Pádua construíram, no âmbito da Pedagogia da Alternância, em defesa das escolas do campo, no período de 2015 a 2019. Os principais resultados destacam a importância da pesquisa-ação no fortalecimento das demandas locais e no processo de denúncia da retirada de direitos educativos das populações do campo. Ademais, os resultados sinalizam que os movimentos sociais populares fortalecem a formação de educadores do campo como política pública de reparação e de questionamento das situações de opressão, dentro e fora das instituições educativas.

Palavras-chave: Educação do Campo; Fechamento de Escolas; Formação de Educadores do Campo; Movimentos sociais.

\section{THE MEANINGS OF STRUGGLES TO DEFEND RURAL SCHOOLS}

School Education in Brazil, mainly in rural schools, is expressed by different colonizing, hegemonic and oppressing aspects that harm the cultures and production modes of country life. Based on such an oppression, Ribeiro (2013) emphasizes that the modern concept of Education still brings along traces that allows us printing the history of winners; in other words, the history of the "winner" bourgeois class between the feudalism/capitalism transition. This History is introduced as that holding the absolute and irreducible truth, and it denies and subordinates the process of learning from experiences, culture and labor. The conditions that have organized, and that still organize, the Brazilian Educational thinking are rooted in the colony profile of power, knowledge and being, which are "visibly linked to political relationships and to the specific ways to think about, and adjust to, socio-ethnic-racial collectives of gender, rural and peripheries, since the colonial times, which remain in place in the republican ideal" (ARROYO, 2014, p. 61).

Since these colonial relationships are still observed in school discipline matrices as domination tool, population social movements have pushed, and still push, the Brazilian State to think over the Education models provided by it, since populations defended by these movements understand that "the Education concepts and practices established to educate them, to civilize them, are set by the ways to think about them, or by the power-knowledge pattern based on how 
they were though in order to be subordinated" (ARROYO, 2014, p. 11). Rural social movements - with emphasis on $\mathrm{MST}^{1}$ - have been putting pressure over the political field by struggling for a new model of society in order to overcome the subordination processes. These struggles include the fight for the right to land and work, the critique to the oppressing educational reality, mainly the educational situation of Brazilian populations living in/from the countryside (CALDART, 2009). These movements embraced the "challenge of conceiving and developing a counter-hegemonic formation, i.e., of formulating and putting into practice an education project integrated to a social-transformation political project leaded by the working class" (MOLINA; SÁ, 2012, p. 327).

As for the normative scope, the Rural Education proposition was implemented through Decree n. 7.352, from November 4, 2010, which provides on the Rural Education policy and the National Education Program in the Land Reform, also known as PRONERA. Social movements thought about the educational dimension of labor and life in the countryside during such an implementation process, given the "relationship the workers set with nature, which is mediated by relationships with oneself and with other workers, it humanizes while produces material and immaterial assets, language, art, knowledge and culture" (RIBEIRO, 2013, p. 44). However, one decade after Decree $7.352 / 2010$ was enacted, it is still possible observing the continuity of an economic and countryside emptying project countrywide. As stated by Schmitz and Castanha (2017, p. 46): "historically, the countryside was naturally turned into a place of delay, where schooling is not important. Nowadays, it is observed through the number of schools that have been closed".

The project to emptying the countryside through the concept of place of disregard is made feasible, as highlights Arroyo (2014, p. 11), through the "concepts, education epistemologies brought from abroad, from the civilized and civilizing center, [...] conceived in the concreteness of the colonizing power/knowledge pattern". The rural Education political project, as an attempt to

\footnotetext{
${ }^{1}$ MST - Movement of Landless Rural Workers - has been leading popular social movements since the 1990s towards Education inclusion as their number one priority; therefore, is it seen "as the most strongly organized movement in almost the whole Brazilian territory" (RIBEIRO, 2014, p. 35).
} 
resist the urban-centered concepts, has been the cause of epistemological and political tension in struggles to fight for the right to education of rural populations. In the last few years, these struggles have been articulated in order to defend the functioning of rural schools, since the social movements understand that having a functioning school is a starting point for school transformation (CALDART, 2010). It is not possible building the counter-hegemonic Rural Education without rural schools; consequently, it gets harder to reinforce social movements to resist the violation of rural populations' fundamental rights.

The presence of UFF's Interdisciplinary Major Degree in Rural Education (LEdoC) in Northwestern Rio de Janeiro State has been changing teachers' formation practices, based on the struggle to keep rural schools working (ANDRADE et al., 2019a). Similarly, other LEdoCs from other institutions, whose educational identity is also moored in the Alternation Pedagogy, feed the "dialectics between circumstances' transformation and self-transformation, which is triggered and demanded by this process (it happens in the praxis)" (CALDART, 2010 , p. 65). The scholar community committed to social struggles and to the right to education, to cooperate with other social actors, has been triggering political tension in the region, since it fights for rural schools. Accordingly, the main aim of the present research is to describe our participation in popular social movements, in the struggle and resistance towards keeping the rural schools in Santo Antônio de Pádua City, RJ, between 2015 and 2019, based on an interpretative approach.

\section{ALTERNATION PEDAGOGY AND ITS DIALOGUE WITH RESEARCH- ACTION: SOCIAL MOVEMENTS UNDER FORMATION}

Not differently from the other regions in the country, the state actions to close rural schools in Northwestern Rio de Janeiro State are based on economic narratives that lead to precariousness, which, in its turn, is used as justification (SCHMITZ; CASTANHA, 2017; RODRIGUES, 2019). According to Rodrigues (2019, p. 30), "the precariousness of rural school infrastructure results from the intentional inefficiency and neglect by the public power to ensure the effectiveness of the Rural Education policy". Different actors got together in a 
non-colonial movement aimed at resistance, and at reinforcing citizenship, by claiming for basic rights provided on the constitution in order to cope with this neglect. These actors substantiate their actions to fight for rural schools based on law n. 12.960, from March 27, 2014. It is an attempt to stop rural, indigenous and quilombola schools to be closed before the "analysis of the diagnostic about the impact of the action and manifestation of the school community" (BRASIL, 2014).

The Interdisciplinary Major Degree in Rural Education, provided by the Northwest Higher Education of Rio de Janeiro State (INFES) of Fluminense Federal University (UFF) has been embracing an essential role in the formation of social resistance movements. This major degree has been articulating local struggles because of its institutional position in forming teachers to act in rural schools; it is also building an education environment to think about "the pedagogical whole featuring the movement, which is then capable of turning each person, who is subject of a pedagogical process mainly focused on its formation" (CALDART, 2004, p. 400). More than the citizenship action featured by the fight for the maintenance of active rural schools, this movement is reinforcing the herein addressed course and its students as participants in several pedagogical actions that emerge from the practices of social resistance movements.

Thus, we seek to describe our experiences forged in the Alternation Pedagogy scope based on popular social movements that think about the organization of social and resistance struggles against the process of closing schools in rural communities in Santo Antônio de Pádua City, RJ. This description follows the interpretative approach, since we understand that "each researcher builds and rebuilds the research problem, which is set by social, historical, cultural and, mainly, epistemological experiences and perceptions, a fact that enables recognizing the existence of a research problem" (ROSSATO; MARTÍNEZ, 2017, p. 344). Accordingly, the present study was built based on the methodological guidance of the research-action, which emphasizes that "problems are captured and solutions are tested throughout action, and with the participation of actors and investigators" (COSTA, 1991, p. 51). This test is made feasible by the application of the political intentionality; this is the reason why the focus of this 
research lies on reporting to change the reality through actions and reasoning; in other words, "it aims at aligning knowledge to change" (DEMO, 1995, p. 231).

The option for adopting the research-action approach is justified by the sense that "the more students are problematized as beings in the world, and with the world, the more challenged they will feel. The more they are challenged, the more they will feel pressured to respond to the challenge. Challenges encompass challenge, itself, in the very action of capturing it" (FREIRE, 2005, p. 80). Therefore, knowledge production acts along with the "struggles by groups that are subordinated to the rise of the knowledge ignored and minimized by hegemonic ideologies" (COSTA, 1991, p. 50). The Interdisciplinary Major Degree in Rural Education stands out for its pedagogical-policy in the organization of the herein highlighted struggle, as emphasized by Andrade and collaborators (2019a; $2019 b)$; it allows the elaboration of the research-action through the Alternation Pedagogy.

The Alternation Pedagogy, which is divided between different spaces/times: University Time (UT) and Community Time (CT), uses its theoretical-practical dialectics to build an authentic and revolutionary praxis to break with the dichotomous logic of colonization that "operates through successive separations and through several reductionisms" (PORTOGONÇALVES, 2005, p. 3). Thus, it promotes self-reasoning by the community that "will lead to the consequent deepening of its awakening and result in its insertion in History, no longer as spectators, by as casting and authors" (FREIRE, 1967, p. 36). Based on such elements, CT at Fluminense Federal University (UFF), in Santo Antônio de Pádua City, RJ, works as social experience laboratory, as stated by Andrade and collaborators (2019a). We can point out three moments that have worked as basis to support the construction of this study proposition, during the formulation of this practice, and in actions beyond it, by thinking about the research-action methodology:

$\checkmark$ Deepen in concepts, historical and political processes of Rural Education elaborated throughout debates and discussion in UT disciplines. 
$\checkmark$ Studies and understanding about the reality in the field, in the assessed county, based on reasoning about the deepened concepts, mainly during CT, supervised internship and work at schools related to the attended discipline; students' daily experiences in Santo Antônio de Pádua's territory.

$\checkmark$ Construction of joined actions by different social actors in movements focused on defending rural schools; these actions are taken based on the possibility of a giving moment.

Accordingly, the aim of the current study is not just to produce knowledge, but also to ethically and politically commit to change reality (COSTA, 1991). At times of disputes triggered by Rural Education, "the concrete fight takes place in and through the construction of social relationships substantiated by cooperation and solidarity" (FRIGOTTO et al., 2020, p. 14). Such a cooperation is consolidated by people who lead the research: a) rural populations in Santo Antônio de Pádua, with emphasis on the rural community from Salgueiro; b) UFF's LEdoC teachers, students and coordinators, as well as the other segments in INFES/UFF's academic community; c) teachers in the municipal education network and in other public services provided by the municipal network. These people not only started a reality that starts to be changed, but they were the main producers of data substantiating the current research.

We dialectically built this collective's collaboration and cooperation - as previously detailed -, which registers the history of present times. It is reinforced by movements focused on confirming the countryside as a place for existence and resistance; it contributes to the formation committed to the defense of human rights, based on democratic principles, with social justice. The following activities were performed within the documentation process: a) interviews and documentaries $^{2}$ - stared by Salgueiro community, local and political leaders; b) field notes; c) conversation rounds; d) assignments for specific disciplines and

\footnotetext{
2 Two documentaries were produced at Community Time scope. Speeches taken from these documentaries will be coded in order to keep participants' secrecy: DOC1 for speeches taken from the first documentary - Memória Social e Resistência: organização comunitária contra 0 fechamento da escola Alice do Amaral Peixoto -; DOC2, for the second documentary - Memória e resistência: estrutura educacional do Noroeste Fluminense.
} 
monographies; e) research conducted in official MEC websites, as well as in national normative documents and municipal laws, helped building our research, as well as the practice observed in several experiences built over the struggles for resistance. Our participation as UFF's LEdoC academic community in resistance movements started when reality was problematized, i.e., from the collective awareness about injustice processes and the denial of basic rights.

\section{RURAL EDUCATION AS POLITICAL STRENGTH: ORGANIZATION OF AND ACTIONS BY RESISTANCE MOVEMENTS}

The Alternation Pedagogy is in the mainstream of debates about a pedagogical policy that reinforces the collective identity of subjects and their struggles within the teaching/learning process at all schooling levels. The Alternation Pedagogy - as it was highlighted in the regulation positions elaborated by the National Education Council, also known as CNE - seeks "constant interaction between students and the reality where they experience their daily lives, in order to promote constant knowledge exchange between their life environment and work, and school" (CNE, 2020). Interaction in this exchange process points towards lack of a single way to make the Alternation dynamics, since it takes place in the specificity of each reality, context, locality, and in their spaces and times, which were thought as spaces/times. Thus, the concept of the right of all is reinforced by the construction that "people have the right to an education that was thought based on their place and participation, which is bond to their culture and to their human and social needs" (CALDART, 2002, p. 18).

The normative milestones in Rural Education highlight the Alternation Pedagogy as "pedagogical instruments that integrate practical knowledge, scientific knowledge, several epistemologies coexisting in the world, subjects' identities and territories within the school scope and in that of other education institutions" (CNE, 2020). According to UFF's LEdoC experience, the Alternation Pedagogy has become concrete based on reports about the local reality, since it unbalances the colonial logic of knowledge, which has been acting as one of the fields set for social, ethnic and gender collective segregation, not just because it denies the case, but because it does not acknowledge it as capable of achieving 
concrete knowledge" (ARROYO, 2014, p. 214). By integrating UT to CT, knowledge production does not happen in the fight for rights, for recognition as collective subjects of rights, mainly as knowledge subjects subordinated to the colonial, racist and Euro-centered logic. UFF's Alternation Pedagogy in counterhegemonic movements reinforces itself within the construction of cross-sectional and multidisciplinary topics that complete each other in the plurality of emerging demands, which will be further detailed below.

\section{ALTERNATION PEDAGOGY IS REDISCOVERING AND REDESIGNING SOCIAL STRUGGLES FOR THE RIGHT TO EDUCATION}

UFF's LEdoC implementation emerged as fundamental element for the construction of the debate about the Alternation Pedagogy and the organization of social struggles in Santo Antônio de Pádua County - RJ. Course implementation - back in 2015 - was the outcome of public call n. 02/2012 by MEC, which enabled the provision of three vacancies for technicians, fifteen vacancies for professors, and on specific funding for the maintenance of the first years of this new major degree. Once implemented at Fluminense Federal University (UFF), the major degree in question reinforced itself as the only one in the institution that has the Alternation Pedagogy as structuring element in its political-pedagogical project. In other words, its discipline matrix structure sets the dialogue between two different spaces/times of learning - the University time (UT) and the Community Time (CT). Both spaces/times set the relationships between different epistemic profiles of students and their communities, and knowledge built from the scientific perspective. A whole series of other public policies and events, which derives from mobilization by rural popular social movements were also essential for the concept of Rural Education and for the definition of rural school. Among them, Bicalho (2018, p. 29) has emphasized:

a) The 1988 Constitution of the Federative Republic of Brazil, Title 1, Article 3, IV; and Chapter III, Section 1, Art. 206; b) Law of Guidelines and Bases of National Education (LDB) n. 9.394/96, Art. 28, 78, 79; c) National Conference of Land Reform Teachers (ENERA), organized in 1997 by rural social movements, in partnership with the University of Brasilia (UnB); d) national Program of Land Reform Education (PRONERA), launched in 1998, along with the National Institute of 
Colonization and Land Reform (INCRA), which is nowadays linked to the Agrarian Development Ministry (MDA); e) Resolution $\mathrm{n} .1$ by the National Education Council (CNE)/ Basic Education Chamber (CEB) from April 3, 2002, Operational Guidelines for Basic Education in Rural Schools; f) Active School Program; g) Rural ProJovem - Land Knowledge; e) Rural ProJovem; f) Program to Support Higher Education in Rural Education Degree (PROCAMPO), launched in 2007, which aims at forming teachers based on knowledge field, through the Alternation Pedagogy, to act in rural schools; g) Law n. 11.947, from June 16, 2009, which provides about the understanding of school food environment and about the Direct Money in the School Program, which is destined to basic education children; $h$ ) Resolution n. 4, from July 13, 2010, which defined the National General Discipline Matrix for Basic Education, according to which, Rural Education is a teaching modality; i) Decree n. 7.352, from November 4, 2010, which provides on the Rural Education Policy and the National Program of Education in the Land Reform (PRONERA); j) national Program of Rural Education (PRONACAMPO), from March 20, 2012; k) National Forum on Rural Education (FONEC); I) Ordinance n. 391, from May 2016, which set the orientations and guidelines for normative organs of the teaching systems about the closing of rural, indigenous and quilombola schools.

Based on these events and policies, the Rural Education Major Degree implementation in Santo Antônio de Pádua (RJ) brought along the concept of Rural Education as rural popular class movement that has intensified the "pressure for public policies to ensure broader access of peasants, from the set of rural workers, to education" (CALDART, 2009, p. 60). This movement has been feeding the resistance struggles to defend rural schools, and it has been, simultaneously, questioning its current role and thinking about its transformation; i.e., the search for a school that works "the interests, policies, culture and the economy of several groups of rural workers [men and women], [...] by producing values, knowledge and technology based on the egalitarian social and economic development of this population" (ARROYO, 2004, p. 53). These conceptions are based on the Alternation Pedagogy role in the organization of local social struggles to defend Rural Education, which is detailed in the chart below. This chart shows the whole trajectory from the major degree implementation to the main activities that were the objects of analysis in the present research. 
Figure 1 - Systematization of fundamental elements for the formation of the social movement to defend Rural Education in Northwestern Rio de Janeiro State

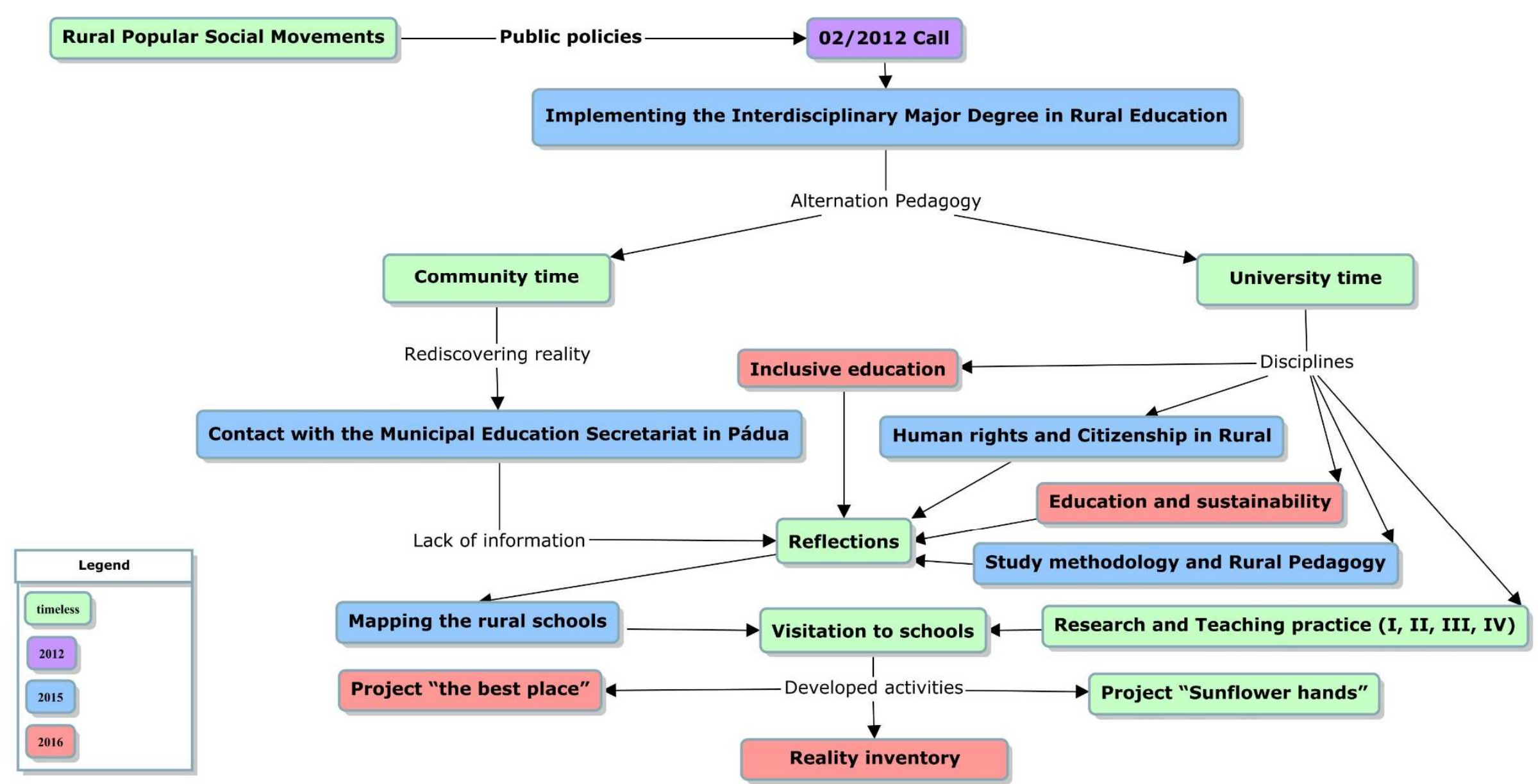

Source: Elaborated by the authors. Research data (2015 - 2018). 
According to Figure 1, the Alternation Pedagogy has been taking a path that has inserted us in the organization after UFF's LEdoC implementation, as well as in the struggle to defend Rural Education in Northwestern Rio de Janeiro State. It also added two university's institutional learning spaces/times policies that join each other and dialogue to build a revolutionary praxis, namely: University Time (UT) and Community Time (CT). Such a process made it possible pointing out the political power of the Alternation Pedagogy, which, based on findings in previous research, proposes some "counter-hegemonic [responses] to the colonialism of knowledge, delimits the theoretical-methodological and epistemological field of Rural Education, based on other readings and on understanding the world and reality" (ANDRADRE et al., 2019a, p. 14). Thus, UT and CT approximate the multiple knowledge field as an attempt to "construir puentes de convergencia entre proyectos intelectuales, entre comunidades interpretativas y entre las disciplinas que estudian lo social-cultural, y también entre éstas y los saberes locales" (WALSH, 2013, p. 14).

Deepening on rural school-related knowledge has been our way to understand the political and epistemological reality by reporting the injustices surrounding us, in UT. The political power of Alternation in CT has been allowing us to rediscover the reality of injustices and to cope with them. Based on the research-action approach, we have started organizing social movements focused on defending rural schools. The act of rediscovering reality - this process happened after we problematized municipal school matters - emerged from the contact among us, the academic community in the herein addressed major degree, members of rural communities and Pádua's Municipal Education Secretariat - RJ. Such a gathering was planned during the CT in the second semester of 2015, which aimed at problematizing UT in order to better understand the situation faced by rural schools in this county. Because of lack of information at this first meeting, the main reflection about this research-action stage concerned the very construction of a database, which started with mapping and visiting rural schools in the assessed county. This process took place through several experiences built in both spaces/times. 
Our hypotheses at the beginning of the research were substantiated by the observed intentional neglect by the State with rural schools. This neglect was featured, but this finding was further analyzed in-depth in a research carried out by Andrade and Rodrigues (2020). This featuring points out that the public power formulates budgetary excuses as an attempt to justify the rural exodus due to lack of infrastructure in rural schools. Our initial perception was reinforced by empirical work and immersion in the local reality, since the closer we got to the Alternation spaces/times reality of each community and school - UT and CT the clearer the evidence that the problem does not regard the budget, but politics.

One of the studies we have carried out in CT aimed at mapping rural schools to elaborate the register of schools featured as rural and the ones taken as rural schools, which are located in districts and assist rural-zone students. This screening allowed starting a dialogue with schools in order to get to know their difficulties and the issues they had to face, as well as to develop activities through teamwork. These partnerships, which are substantiated by the research-action in the UT scope, just as highlighted by Andrade and Rodrigues (2020), linked components of the discipline matrix elaborated for Rural Education Major Degree to local rural communities in order to question the injustice and neglect realities faced by them. Based on our perception during the process to elaborate the present study, among the main disciplines that have triggered actions in the municipality, it is possible highlighting 'Inclusive Education'; 'Study Methodology and Rural Education'; 'Human Rights and Citizenship in the Countryside'; 'Education and Sustainability'; 'Research and Teaching Practice' (I, II, III and IV). We have developed concrete projects from these components, among them, one finds: "Sunflower Hands" and "The best place in the world is here".

Activities such as theater plays, pedagogical visitations, workshops on sustainability and agro-ecology, and conversation rounds with the community were developed by the aforementioned disciplines and projects; some reforms in rural schools even emerged from them. These activities were elaborated in both spaces/times, and it allowed approximating countryside subjects to community knowledge. Therefore, we have built the Reality Inventory, which is an activity that has emerged from the dialectical power provided by the Alternation 
Pedagogy within the horizontal status among communities-students-teachers, which is consolidated "by the dialectic process set between reporting the dehumanizing situation and the announcement of its overcoming" (FREIRE, 2000 , p. 81). The reality inventory, which was elaborated at Alice do Amaral Peixoto School, made it possible rediscovering the geography of the countryside - social and epistemic - by detailing information that was initially simple, but that enabled organizing important features that have disclosed reality; in other words, its location and access, teacher and student groups in the school, income sources in the regions and students' income sources, public assistance services, biodiversity, among others.

After the real situation was disclosed by the reality inventory, the struggling for transformation started to be redesigned based on the political power of the Alternation Pedagogy, which "assumes the synergy, integration and entanglement that allows breaking with the theory and practice, abstract and concrete, school knowledge and traditional knowledge, formation and product, intellectual work and manual labor, dichotomy" (CNE, 2020, p. 4). Accordingly, all the activities introduced in Figure 1 aimed at improving the education quality of "students who needed to learn today, rather than wait for the solution of school issues" (CALDART, 2010, p. 69). However, the social movement that was rising knew that such activities were not enough, as recorded in the research by Rodrigues (2019). Anacleto Eccard Junior School was closed in late 2016, and João Neves Brum School was closed in July 2017; therefore, not even the pedagogical activities without financial resources from the city hall were able to keep the schools opened. This process pointed towards the real intention behind the public power's actions: closing the schools.

After the two schools were closed, the social movement that was under organization process understood that only the collective struggle would have kept the schools opened - this action is, after all, a pedagogical activity. It was possible understanding that reality is a construction and that subjects can change it by rediscovering this reality, mainly by decoding reality by deepening in concepts about the formation of rural teachers. The association between theory and practice, which was based on Alternation, evidenced that the "lucid insertion in 
reality, in the historical situation, led to the critique over this very situation and to the will to change it" (FREIRE, 2005, p. 61). Thus, along with local communities, we turned ourselves - as social movement - into historical subjects aimed at questioning the truths and into agents of transformation. According to Arroyo (2014, p. 315), "deeply knowing the complex historical processes concerning the non-acknowledgement or the enactment of its non-existence, inferiority, subhumanity, sub-citizenship is the requirement to think about public policies"

The Alternation Pedagogy, as the main counter-hegemonic device, sets "the power of the action-reflection of social practices in territories - geographic and epistemological - of Rural Education, and triggers actions to reinforce citizenship and the organization of social struggles" (ANDRADE, et al., 2019a, p. 27). When it comes to the concrete results of the current study, and based on a constant dialogue between students' reality and their theoretical formative construction, the Alternation Pedagogy gathers the social struggles for the right to education and for the rounded teaching/learning process. It is so, because when one is committed to the counter-hegemonic Pedagogy, one can understand that "las luchas sociales también son escenarios pedagógicos donde los participantes ejercen sus pedagogías de aprendizaje, desaprendizaje, reaprendizaje, reflexión y acción" (WALSH, 2013, p. 29). We gathered in different voices that echo in defense for the right to Education, for the right to have right, by building scenarios and the political pedagogical what-to-do. These voices argue, as highlighted by Arroyo (2014, p. 330), "the ones classified as subcitizens" and, at the same time, "put on the political stage the most dynamic citizenship".

\section{ALTERNATION PEDAGOGY AND THE ORGANIZATION OF SOCIAL STRUGGLES: POLITICAL TENSION IN SANTO ANTÔNIO DE PÁDUA CITY}

The attacks against Education, mainly against Rural Education, have forged actors who put themselves on the scene to defend constitutional rights. As evidenced by Cunha (2001, p. 65), "the State, given its omission or because of its anti-democratic policies, has been the real booster of social movements". By reporting the closing of Anacleto Eccard Junior and João Neves Brum schools, 
the steps taken 'on the hot asphalt at dusk' have marked the first organized act, which counted on the participation of UFF's LEdoC, at Santo Antônio de Pádua's downtown area - RJ. The rural population and members of the Rural Education Major Degree of UFF, among other segments and individuals in the collectivity, remained resistant and started a resistance movement against the rural deletion process. Such a deletion is not contemporary, it has been in place for decades in this county, and it has been expressed by the closing of many schools in the countryside. 
Figure 2 - Systematization of the social organization process in defense of Rural Education in Northwestern Rio de Janeiro State

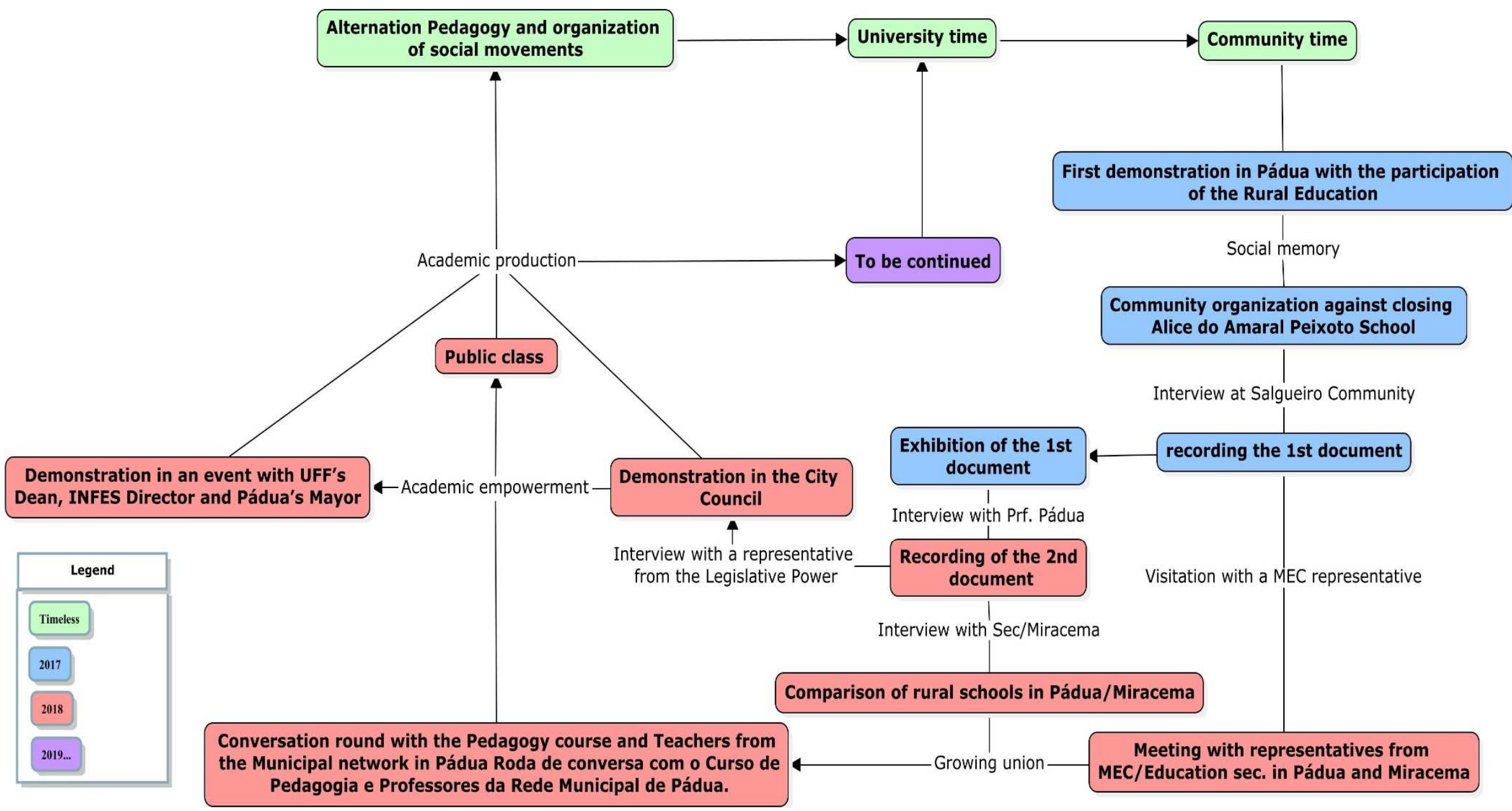

Source: Elaborated by the authors. Research data (2015/2018). 
The first demonstration against the closing of rural schools that have counted on the participation of UFF's LEdoC made it possible observing that, similar to what was highlighted by Sader (1988, p. 32), "small actions that would be seen as insignificant so far, or the reinforcement of impotence, now start to get new overtones", mainly because of the gathering of subjects who start to build collectivity. As pointed out by Marx and Engels (2020, p. 142), "the real outcome of their struggles is not immediate success, but the growing union". Based on the experience with the first social organization to stop the closing of rural schools, the local public power faced other movements that ended up gaining political power; therefore, these movements questioned the anti-policies by the State. Salgueiro and Arraialzinho communities, along with other subjects in the struggle process, consolidated the first effective resistance act to defend Alice do Amaral Peixoto and José Lavaquial Biosca schools. The message left by this movement, as reported by a resident in the rural neighborhood of Salgueiro in the First Documentary:

is that we can never stop fighting for our rights, that we have the right to have education here in our neighborhood. We have the feeling that it is worth fighting for, a concern, the communication of people who participated in the meeting, it was all worth doing (DOC 1).

We elaborated documentaries because we understood the relevance of such an event and all the power of this resistance act, but also to picture that the fight would not be over after this ephemeral triumph. They aimed at registering in audio and video - the whole resistance and struggle processes, which were essential for the union of collectivity to keep on growing. We started to design the first documentary substantiated by the CT activities; in other words, in its "social, political and epistemological importance, since it puts the student back in its own community, rather than just [putting it] into its student condition, but also in the position of potential teacher, as the result of such a reality" (ANDRADE et al., 2019a, p. 27). This documentary was called "Social Memory and resistance: community organization against Escola Alice do Amaral Peixoto closing", which aimed at registering the social memory of the collective struggle, as well as to 
preserve and keep the memory of this historical fact. Our first documentary was recorded along with the stars of this movement: Salgueiro community.

This movement got into the educational reality of the herein assessed municipality to dialogue with several actors who remained in the collectivity at recent struggles. As reported by a resident to the First Documentary, "It was worth fighting for, but perhaps it is not over, yet" (DOC 1). Accordingly, we all knew that it was essential keeping the collective mobilization and, as strategy, we thought about a Second Documentary - Memory and resistance: educational structure in Northwestern Rio de Janeiro State -, which was recorded with the leadership that was displacing within the education network, in the county. This documentary highlights the relevance of a public-school teacher. The initial proposition of the Second Documentary lied on establishing a dialogue about the backstage of the Educational System in the county, on disclosing its reality and on thinking about its transformation. Among the several neglects, one finds salary issues, didactic material and school infrastructure, which were in the mainstream of the main speeches. On the other hand, this dialogue exceeded the territorial borders of Santo Antônio de Pádua - which does not pay the national minimum wage for teachers - and got to the agenda about the contrast between neighbor cities. As reported by the leader (DOC2):

We earn a salary that cannot afford us, at all, and it is completely different from the salary of our colleagues in Miracema, the neighbor city. It is a smaller city, which has less students, and FUNDEB is naturally similar, i.e., a smaller counting, and there, we earn more than we earn here.

In face of this new framework, we sought to set a dialogue with the Municipal Education Secretariat of Miracema, which accepted our invitation to join the Second Documentary. Differently from the education in Pádua County, which closes rural schools and segments, Miracema County is "developing a project that exceeds $\mathrm{R} \$ 50,000.00$ for a school with 17 students" (DOC2). Two other actions, besides investments in schools' infrastructure to improve education and to reinforce students' will to remain in the region, were outstanding: full time school shift and larger number of employees, mainly teachers who share child education classes in first segment classes (DOC2). In order to compare such 
realities, after recording the second documentary, we visited the rural schools closed in Pádua and the schools that have received investments in Miracema. After getting deeper and deeper in the educational reality of Pádua County, it became evident that closing rural schools is a project that has been in place in most of the Brazilian territory. According to Bicalho and Bezerra (2018, p. 102),

\begin{abstract}
In the last 15 years, we have been daily dealing with the illegal and random closing of rural schools in Brazil. According to INCRA National Institute of Colonization and Land Reform -; PRONER National Program of Land Reform Education; UNESCO - United Nations Education, Science and Culture Organization; IPEA - Institute of Applied Economic Research, and PNERA - Report on the II National Survey on Land Reform Education sources, approximately 32,512 schools were closed in the last decade.
\end{abstract}

In order to cope with this project, we thought about the need of exhibiting the first documentary, and it actually was done during the UT, on August 21, 2018, with the presence of some residents who have reported the injustices against the rural community in the county. This exhibition took place in INFES/UFF patio, and it aimed at mobilizing either students of Rural Education or INFES' academic community passing by the patio for joining the struggle by resistance movements. The idea was to introduce the reality of the main local struggle to them. This struggle did not take long to once again be necessary; at this time, it took place against the closing of the second segment of the Elementary School - from the $2^{\text {nd }}$ to the $9^{\text {th }}$ year - at Antônio Teixeira Jardim and Professor José Pinto de Souza schools in São Pedro and Marangatu districts rural districts of Santo Antônio de Pádua County - RJ. We joined these communities, along with new movements, in a resistance act marked by the Occupation of the City Council - November 26, 2018. We carried plates reporting the closing of these segments, by pointing out that this action was going against the will of the population.

The movement organization, at research-action scope, got sort of close to what Andrade and Corrêa (2020, p. 123) highlighted as the advantages of this methodology: the epistemic power of a report, since "professionals in this field, as social teachers, can become agents to transform thematic-spaces". According to them, the research-action can "restate agendas, reinforce community 
commitment and encourage protagonism in the struggle for social, political, economic and environmental rights" (ANDRADE; CORRÊA, 2020, p. 123). These elements were also observed in the construction of a movement against the closing of rural schools in Northwestern Rio de Janeiro State. We also interviewed the only city councilor that stood against the maintenance of the rural schools, when it comes to the availability of the second segment of Elementary School - from the $6^{\text {th }}$ to the $9^{\text {th }}$ year.

The Second Documentary gathered three interviews with the following collaborators: a) one teacher from the Municipal Network in Pádua; b) The Education Secretary from Miracema City; c) one city councilor from Pádua County. Assumingly, the struggle reality was the greatest popular demonstration against the violation of the right to Rural Education in Northwestern Rio de Janeiro State, by the State - it resisted for one year. However, the asymmetric forces did not allow the movement to stop the daily attacks and the precariousness process of Education in the most vulnerable areas. These attacks got wider and were institutionalized by the closing of the second segment in these schools - the local power did not take into account the constitutional right of the population. These closing processes disclosed the real intention of mischaracterizing the schools in the district, as rural schools, which is a strategy to scape law n. $12.960 / 2014$ - it prohibits the closing of rural schools before the analysis of impacts and the popular manifestation of the affected community. Based on Schmitz and Castanha (2017, p. 41), it has been

The hard reality faced by rural schools that, even with the mobilization of social movements articulated with society, that have pressured/and pressure for the creation of a legislation to provide on schools' closing, we cannot be sure, in practice, that rural schools will not be closed.

We hosted a representative from the Ministry of Education (MEC) during the time when the second segment of the Elementary School was closed in the rural schools - which lasted one year, given the attempts to demobilize the resistance movements. This visitation aimed at gathering information about the reality of the process to institutionalize the Interdisciplinary Rural Education Major Degree at UFF, as well as to understand the course's insertion in the local 
community. Accordingly, a meeting was set by MEC's representative; it counted on the participation of the Municipal Education Secretaries from Pádua and Miracema, of UFF's LEdoC coordination and of students - representatives from the herein addressed Major Degree. The meeting approached the main agenda of the academic community linked to this major degree: explanations about the attempts to close rural schools and rural teachers' insertion in the agenda of secretariats in the region.

The municipal public power from Santo Antônio de Pádua was questioned about the closing of the rural schools during the meeting with MEC's representative. Based on his answers, some items were not in compliance with reality, mainly the denial of negotiations about the attempt to avoid the closing of rural schools. The true answer, in opposition to the distorted speech presented during the meeting, came one year later: the public power closed the second segment of Elementary School - from the $6^{\text {th }}$ to the $9^{\text {th }}$ year - in schools in Marangatu and São Pedro districts; it kept on going with attacks against rural schools in other districts and rural neighborhoods, among them Alice do Amaral Peixoto School. Because of this new action by the public power, there were news about the likely closing of other schools in the hallways of schools in order to monitor possible future mobilizations and to, then, act based on the circumstances.

A conversation round was carried out along with INFES' Pedagogy major degree in order to react to the straight attacks and rumors in districts and rural neighborhoods; it marked the organization of two resistance acts: the first one was a demonstration at INFES/UFF auditorium during the events with UFF's Dean, INFES' Director and Santo Antônio de Pádua Mayor, back on December 11, 2018; the second act was the public class about the topic "Rural Education and Human Rights", lectured by a UFF's LEdoC professor, on December 12, 2018. These movements ensured the continuity of Alice do Amaral Peixoto School, and the availability of Child Education classes and of the first segment of Elementary School - from the $1^{\text {st }}$ to the $5^{\text {th }}$ year.

Despite all the struggles, the threats of closing rural schools remain real and follow the same emptying and precariousness logic based on governmental 
discourses. Among such discourses, Andrade and Rodrigues (2020) highlight the "small number of students, lack of resources for reforms, high cost of each student in comparison to teaching in urban zones, cost with transportation, among others". Given the violation of the right to Rural Education, "youngsters are not settling in the countryside, they are leaving to the city to seek education and, in most cases, they never return, a fact that leads to countryside emptying" (SCHMITZ; CASTANHA, 2017, p. 41). Bicalho and Bezerra (2018, p. 102) added to it by stating that "lack of schools and their closing is the ultimate factor for such a migration, which is added to the authoritarian and conservative profile observed in rural schools, which are mostly distant from peasants' specificities". On the other hand, the open Rural School, besides the possibility of keeping youngsters in the countryside, helps building a high-quality education based on students' very reality, as highlighted in a speech in our second documentary:

Can you think about a school where you can talk about production and make it real? We could be talking about production, we could be talking about sustainability, we could be talking about research in the school. We could be in line with the research groups, either academic or others (DOC2).

This last speech represents one of the critical questionings that UFF's LEdoC triggers in subjects based on the Alternation Pedagogy. These struggles have several purposes, such as discussing the concept of countryside as a place of obsolescence, because it reinforces the dialectical materiality of reality as research that, at this very moment, is expressed by the political claim for the maintenance of rural schools. Reality still regards struggling! Based on such a scenario, one can constantly see the schools resisting and the social collectives getting mobilized to claim for the right to Rural Education. Just as expressed in the speech from the Second Documentary, "It was right after this movement of yours, and of other districts, that we also joined it and started to demonstrate. Actually, we thank UFF, without UFF's help in this process, we wouldn't have made it" (Report about the resistance at José Lavaquial Biosca School, in Arraialzinho neighborhood). This pedagogical policy allowed us to interact with the academic community and with rural populations in the region, as well as to build resistance and to reinforce the concept that the countryside is a place of 
knowledge, struggles, epistemologies and, mostly, of life reproduction, because...

When they fight for the school or for the university, they defend their right to knowledge, to science, to technologies, but also react against a knowledge that neglects their knowledge, their literacy and cultures as inaccuracy, mysticism, political irrationality (ARROYO, 2014, p. 225).

As a response to such a colonial thinking that disregards the countryside, the Alternation Pedagogy allows opening paths for the local communities' demands to be taken into consideration in, and outside, the university. As subjects in the countryside start to occupy the university and the academic sphere with questions in compliance with their reality, they will also question their representation in these spaces by stating themselves as existing beings and as "real" questioners. In other words, they restate themselves as "subjects of their own formation process in order to build themselves as such" (CALDART, 2009, p. 60). This process reinforces the debate and the mobilization of social struggles in defense of rural schools; similarly, and it restates this population as knowledge producers. Accordingly, most of the academic production by UFF's LEdoC, in partnership with rural communities in Northwestern Rio de Janeiro State, has been built in defense of rural schools in the municipality; therefore, it consolidates our occupation in places of knowledge. Similarly, we report injustices and the lack of fundamental rights, as well as reinforce other resilient movements and struggles.

\section{RURAL EDUCATION IN CONTINUITY MOVEMENTS...}

The aim of the present research-action - at the Alternation Pedagogy scope, and beyond it - is to gather systematization at the beginning of a social movement that is still far from its end, which questions reality and counts on several on-going activities. It is leaving its mark in the assessed county and is showing that UFF's LEdoC is more active than ever in resistance and struggle movements in defense of rural schools, as well as in defense of other minorities. This aspect marks such a mutual reinforcement, as the community understands 
Rural Education as collective construction, community-teachers-students, the struggle gets stronger and larger, and gives itself the real potential we expect from it. The college major degree in question has potentiated social struggles through its critical insertion in students' reality and through its consolidation within territories under dispute based on dialogical movements. This major degree is reinforced as it reinforces social movements immersed in the local reality.

Assumingly, it holds its own political, social and epistemological construction, which is forged in the peasant popular classes and opens path for scholars towards other knowledge fields built over the struggle for changing the reality of Rural Education in Northwest Rio de Janeiro State. Thus, it restates the importance of the Major Degree in Rural Education in the agenda, in order to ensure the maintenance of rural schools in the county, as well as the relevance of these movements to restate this major as the proposition to form subjects ready to change society. The social movement used the Alternation Pedagogy against the closing of rural schools in Northwestern Rio de Janeiro State, and it is breaking the colonial pedagogical tradition that, historically, has been acting to put rural populations aside the construction of history; in other words, as mere spectators of political actions. Therefore, the proposition by the Alternation Pedagogy, embraced by UFF's LEdoC, fosters different perspectives about the rediscovery movements by redesigning the emancipatory struggles at the public, social, epistemological and academic spheres to fight for the rural schools.

\section{REFERENCES}

ANDRADE, F. M. R.; NOGUEIRA, L. P. M.; NEVES, L. C.; RODRIGUES, M. P. M. Educação do Campo em giro decolonial: a experiência do Tempo Comunidade na Universidade Federal Fluminense (UFF). Revista Brasileira de Educação Do Campo. n. 4, e7178, 2019a.

ANDRADE, F. M. R; NOGUEIRA, L. P. M.; RODRIGUES, M. P. M. Tempo Comunidade - espaçotempo potencializador de experiências na formação de educadores do campo. In: COSTA, Alvaro Daniel (Org.). Cultura, cidadania e políticas públicas 2. Ponta Grossa (PR): Atena Editora, p. 154-163, 2019b.

ANDRADE, F. M. R.; CORRÊA, M. S. T. Pedagogias e mulheres em movimentos: enfrentamentos à violência doméstica. 1. ed. - Curitiba: Appris, 2020. 
ANDRADE, F. M. R.; RODRIGUES, M. P. M. Escolas do Campo e Infraestrutura: aspectos legais, precarização e fechamento. Educação em Revista. v. 36, Belo Horizonte, 2020.

ARROYO, M. G. Outros Sujeitos, Outras Pedagogias. 2.ed. - Petrópolis, RJ: Vozes, 2014.

ARROYO, M. G. Formação de Educadores do Campo. In: CALDART, R. S. et al. (Org.). Dicionário da Educação do Campo. Rio de Janeiro, São Paulo: Escola politécnica de Saúde Joaquim Venâncio, Expressão Popular, p. 361-367, 2012. ARROYO, M. G.; CALDART, R. S.; MOLINA, M.C. Por uma educação do campo. Petrópolis: Vozes, 2004.

BICALHO, R. A formação do educador de jovens e adultos e os movimentos sociais do campo. Revista Educação Popular, Uberlândia, v. 17, n. 2, maio/ago., 2018, p. 21-34.

BICALHO, R.; BEZERRA, S. F. A influência histórica dos movimentos sociais em favor das políticas públicas de educação do campo. Cadernos CIMEAC, [S.I.], v. 8, n. 1, jul., p. 94-115, 2018.

BRASIL. Lei n. 12.960, de 27 de março de 2014. Altera a Lei no 9.394, de 20 de dezembro de 1996, que estabelece as Diretrizes e Bases da Educação Nacional, para fazer constar a exigência de manifestação de órgão normativo do sistema de ensino para o fechamento de escolas do campo, indígenas e quilombolas. Available at: http://www.planalto.gov.br/CCIVIL_03/_Ato20112014/2014/Lei/L12960.htm. Retrieved November 2020.

BRASIL. Lei n. 9.394, de 20 de dezembro de 1996. (1996, 23 de dezembro). Estabelece as Diretrizes e Bases da Educação Nacional. Available at: http://www.senado.gov.br/sf/legislacao. Retrieved October, 2020.

BRASIL. Presidência da República. Decreto no 7.352, de 4 de novembro de 2010. Dispõe sobre a política de educação do campo e o Programa Nacional de Educação na Reforma Agrária - PRONERA. Available at: http://www.planalto.gov.br/ccivil_03/_ ato20072010/2010/decreto/d7352.htm. Retrieved October 2020.

CALDART, R. S. Educação do campo. In: CALDART, R. S. et al. (Org.). Dicionário da Educação do Campo. Rio de Janeiro, São Paulo: Escola politécnica de Saúde Joaquim Venâncio, Expressão Popular, p. 259-267, 2012. CALDART, R. S. Educação do Campo: notas para uma análise de percurso. Trab. Educ. Saúde, Rio de Janeiro, v. 7 n. 1, p.35-64, 2009.

CALDART, R. S. O MST e a escola: concepção de educação e matriz formativa. CALDART, R. S. (Org.). Caminhos para a transformação da escola: reflexões 
desde a prática da licenciatura em Educação do Campo. 1. ed. São Paulo: Expressão Popular, p. 63-83, 2010.

CALDART, R. S. Pedagogia do Movimento Sem Terra. 3.ed. - São Paulo: Expressão Popular, 2004.

CALDART, R. S. Por Uma Educação do Campo: traços de uma identidade em construção. In: KOLLING, Edgar Jorge et al. (Orgs.). Educação do Campo: Identidade e Políticas Públicas. - Brasília, DF: Articulação Nacional por uma Educação do Campo, p. 147-158, 2002.

CNE - Conselho Nacional de Educação. Proposta de regulamentação da Pedagogia da Alternância. Brasília, 2020. Available at: http://portal.mec.gov.br/docman/junho-2020-pdf/146891-texto-referenciapedagogia-da-alternancia/file. Retrieved August 2020.

COSTA, M. C. V. A caminho de uma pesquisa-ação crítica. Educação e Realidade. V.16 nํㅜ 2, jul. dez, p. 46-52, 1991.

CUNHA, L. A. Movimentos Sociais, Sindicais e Acadêmicos. In Educação, Estado e Democracia no Brasil. 4aㅡ ed. - São Paulo: Cortez; Niterói, RJ: Editora da Universidade Federal Fluminense; Brasília, DF: FLACSO do Brasil, Biblioteca da educação. Série 1. Escola; v. 17, cap. 2, p. 57-72, 2001.

DEMO, P. Metodologia cientifica em ciências sociais. - 3. ed. rev. ampl. São Paulo: Atlas, 1995.

FREIRE, P. Educação como prática da liberdade. Rio de Janeiro: Paz e Terra, 1967.

FREIRE, P. Pedagogia da Indignação: cartas pedagógicas e outros escritos. São Paulo: UNESP, 2000.

FREIRE, P. Pedagogia do oprimido. Rio de Janeiro: Paz e Terra, 2005.

FRIGOTTO, G. et al. Introdução. In: FRIGOTTO, G. et al. (Org.). História, Natureza, Trabalho e Educação. 1a ed. São Paulo: Expressão Popular, p.1122, 2020.

INEP - Instituto Nacional de Estudos e Pesquisas Educacionais Anísio Teixeira. Catálogo de Escolas. Available at: https://www.gov.br/inep/pt-br/acesso-ainformacao/dados-abertos/inep-data/catalogo-de-escolas. Retrieved March 2020.

MARX, K.; ENGELS, F. Burgueses e Proletários (1848). In: FRIGOTTO, G. et al. (Org.). História, Natureza, Trabalho e Educação. 1ª ed. São Paulo: Expressão Popular, p. 133-146, 2020. 
MOLINA, M. C.; SÁ, L. M. Escola do Campo. In: CALDART, R. S. et al. (Orgs.). Dicionário da Educação do Campo. Rio de Janeiro, São Paulo: Escola politécnica de Saúde Joaquim Venâncio, Expressão Popular, 2012 Dicionário da Educação do Campo, p. 326-332, 2012.

MST - Movimento dos Trabalhadores Rurais Sem Terra. Caderno de Educação n. 13: Dossiê MST escola: documentos e estudos 1990-2001. São Paulo, SP: Setor de Educação, 2005.

NEVES, L. C. et al., Memória social e resistência: organização comunitária contra o fechamento da escola Alice do Amaral Peixoto. In. COSTA, Álvaro Daniel (org.). Cultura, cidadania e políticas públicas. v. 4. Ponta Grossa (PR): Atena Editora, p. 130-137, 2019.

PORTO-GONÇALVES, C. W. Apresentação da edição em português. In: Lander, Edgardo (Org.). Colonialidade do poder, eurocentrismo e América Latina. A colonialidade do saber: eurocentrismo e ciências sociais. Perspectivas LatinoAmericana. Colección Sur Sur. CLACSO, Ciudad Autónoma de Buenos Aires, p. 3-5, 2005.

RIBEIRO, M. Movimento Camponês Trabalho e Educação: liberdade, autonomia, emancipação: princípios/fins da formação humana. 2.ed. - São Paulo: Expressão Popular, 2013.

RODRIGUES, M. P. M. A precarização enquanto estratégia de fechamento de escolas do campo: uma análise da infraestrutura de três escolas do Noroeste Fluminense. Trabalho de Conclusão de Curso (Licenciatura Interdisciplinar em Educação do Campo) - Universidade Federal Fluminense, Santo Antônio de Pádua - RJ, 2019.

ROSSATO, M.; Martínez, A. M. A metodologia construtiva-interpretativa como expressão da Epistemologia Qualitativa na pesquisa sobre o desenvolvimento da subjetividade. Investigação Qualitativa em Educação, v. 1, p. 343-352, 2017.

SADER, E. Quando Novos Personagens Entraram em Cena. Experiências, falas e Lutas dos Trabalhadores da Grande São Paulo: 1970-80. Rio de Janeiro: Paz e Terra, 1988.

SCHMITZ, M. T.; CASTANHA, A. P. Fechamento de escolas do campo: o caso da Escola Estadual do Campo Canoas - Cruzeiro do Iguaçu - PR. Imagens da Educação, v. 7, n. 1, p. 38-48, 2017.

WALSH, C. Pedagogías decoloniales: prácticas insurgentes de resistir, (re) existir y (re) vivir. Abya Yala, 2013. 